\title{
Growth, Pod, and Seed Yield, and Gas Exchange of Hydroponically Grown Peanut in Response to $\mathrm{CO}_{2}$ Enrichment
}

\author{
K. Stanciel ${ }^{1}$, D.G. Mortley ${ }^{2}$, D.R. Hileman ${ }^{3}$, P.A. Loretan ${ }^{4,5}$, \\ C.K. Bonsi ${ }^{4}$, and W.A. Hill ${ }^{4}$ \\ Departments of Agricultural Sciences and Biology, Tuskegee University, \\ Tuskegee, AL 36088
}

Additional index words. Arachis hypogaea, nutrient film technique, hydroponics, advanced life support

\begin{abstract}
The effects of elevated $\mathrm{CO}_{2}$ on growth, pod, and seed yield, and gas exchange of 'Georgia Red' peanut (Arachis hypogaea L.) were evaluated under controlled environmental conditions. Plants were exposed to concentrations of 400 (ambient), 800, and 1200 $\mu \mathrm{mol} \cdot \mathrm{mol}^{-1} \mathrm{CO}_{2}$ in reach-in growth chambers. Foliage fresh and dry weights increased with increased $\mathrm{CO}_{2}$ up to $800 \mu \mathrm{mol} \cdot \mathrm{mol}^{-1}$, but declined at $1200 \mu \mathrm{mol} \cdot \mathrm{mol}^{-1}$. The number and the fresh and dry weights of pods also increased with increasing $\mathrm{CO}_{2}$ concentration. However, the yield of immature pods was not significantly influenced by increased $\mathrm{CO}_{2}$. Total seed yield increased $33 \%$ from ambient to $800 \mu \mathrm{mol} \cdot \mathrm{mol}^{-1} \mathrm{CO}_{2}$, and $4 \%$ from 800 to $1200 \mu \mathrm{mol} \cdot \mathrm{mol}^{-1} \mathrm{CO}_{2}$. Harvest index increased with increasing $\mathrm{CO}_{2}$. Branch length increased while specific leaf area decreased linearly as $\mathrm{CO}_{2}$ increased from ambient to 1200 $\mu \mathrm{mol} \cdot \mathrm{mol}^{-1}$. Net photosynthetic rate was highest among plants grown at $800 \mu \mathrm{mol} \cdot \mathrm{mol}^{-1}$. Stomatal conductance decreased with increased $\mathrm{CO}_{2}$. Carboxylation efficiency was similar among plants grown at 400 and $800 \mu \mathrm{mol} \cdot \mathrm{mol}^{-1}$ and decreased at $1200 \mu \mathrm{mol} \cdot \mathrm{mol}^{-1} \mathrm{CO}_{2}$. These results suggest that $\mathrm{CO}_{2}$ enrichment from 400 to $800 \mu \mathrm{mol} \cdot \mathrm{mol}^{-1}$ had positive effects on peanut growth and yield, but above $800 \mu \mathrm{mol} \cdot \mathrm{mol}^{-1}$ enrichment seed yield increased only marginally.
\end{abstract}

The use of biological systems for life support in space has been studied since the early 1950 s, with emphasis on the use of algae to help regenerate $\mathrm{O}_{2}$ through photosynthesis (Golueke and Oswald, 1964; Krall and Kok, 1960). In the late 1970s, the National Aeronautics and Space Administration (NASA) created the Controlled Ecological Life Support System (CELSS) program to promote research for long-term advanced life support (ALS) (MacElroy and Bredt, 1985). Among the concepts considered for ALS is the use of higher plant photosynthesis to provide food and $\mathrm{O}_{2}$, while removing $\mathrm{CO}_{2}$ produced by humans and other heterotrophs. Plant transpiration may also be utilized to produce potable water. Selected for the high protein $(22 \%$ to $30 \%$ ) and oil content ( $44 \%$ to $56 \%$ ) of the seed

\footnotetext{
Received for publication 21 Dec. 1998. Accepted for publication 10 May 1999. Contribution No. 309 of the George Washington Carver Agricultural Experiment Station, Tuskegee Univ. This research was supported by funds from the U.S. National Aeronautics and Space Administration (Grant No. NAG100024) and USDA/CSRS (Grant No. ALX-SP-1). We wish to thank Dr. Bill Branch of the Univ. of Georgia Experiment Station for providing the seeds. The cost of publishing this paper was defrayed in part by the payment of page charges. Under postal regulations, this paper therefore must be hereby marked advertisement solely to indicate this fact. ${ }^{1}$ Former Graduate Student.

${ }^{2}$ Research Associate Professor.

${ }^{3}$ Associate Professor.

${ }^{4}$ Professor.

${ }^{5}$ Deceased 17 Oct. 1998.
}

(Ahmed and Young, 1982), peanut is among several candidate crops for ALS research.

The growth and development of peanut have been widely studied (Bagnall and King, 1991; Chen and Sung, 1990; Florh et al., 1990; Hardy and Havelka, 1977; Ketring, 1984). Bhagsari and Brown (1976) evaluated the effects of increased $\mathrm{CO}_{2}$ on net photosynthesis and leaf characteristics of several peanut genotypes. Net photosynthesis increased linearly for some genotypes as $\mathrm{CO}_{2}$ concentration increased from 300 to $600 \mu \mathrm{mol} \cdot \mathrm{mol}^{-1}$. Hardy and Havelka (1977) grew peanut from anthesis to senescence at ambient $\left(350 \mu \mathrm{mol} \cdot \mathrm{mol}^{-1}\right)$ or $1500 \mu \mathrm{mol} \cdot \mathrm{mol}^{-1} \mathrm{CO}_{2}$ in open-top field chambers. They reported that above-ground biomass was $50 \%$ greater for plants grown at $1500 \mu \mathrm{mol} \cdot \mathrm{mol}^{-1}$ than for those grown under ambient conditions. The increased biomass was attributed to decreased photorespiration, delayed senescence, and retention of more reproductive structures (flowers and gynophores). Chen and Sung (1990) evaluated the effects of $\mathrm{CO}_{2}$ at 340 (ambient) and 1000 $\mu \mathrm{mol} \cdot \mathrm{mol}^{-1}$ from seed filling in Virginia-type peanut. High $\mathrm{CO}_{2}$ increased biomass and pod yields. Marketable seed yield was similar, however, because more than two-thirds of the pods on plants grown at $1000 \mu \mathrm{mol} \cdot \mathrm{mol}^{-1} \mathrm{CO}_{2}$ were unfilled. They hypothesized that increasing the $\mathrm{CO}_{2}$ at the seed filling stage maximized competition among developing seeds and pegs, reducing seed growth.

Leaf photosynthetic rate was consistently higher at $1000 \mu \mathrm{mol} \cdot \mathrm{mol}^{-1}$ than at 340 $\mu \mathrm{mol} \cdot \mathrm{mol}^{-1} \mathrm{CO}_{2}$ (Chen and Sung, 1990). In both treatments, photosynthesis was saturated at an intercellular $\mathrm{CO}_{2}\left(\mathrm{C}_{\mathrm{i}}\right)$ of $\approx 600 \mu \mathrm{mol} \cdot \mathrm{mol}^{-1}$. The estimated $\mathrm{CO}_{2}$ compensation points were 50 for the control (ambient) and 90 $\mu \mathrm{mol} \cdot \mathrm{mol}^{-1}$ for plants grown under high $\mathrm{CO}_{2}$, and carboxylation efficiency was higher at $1000 \mu \mathrm{mol} \cdot \mathrm{mol}^{-1}$.

In spite of concerns for increasing atmospheric $\mathrm{CO}_{2}$, only short-term studies have been conducted on the peanut. None of these studies was carried out in controlled environments. Closed environments utilized for human life support in space may reach partial pressures of 5000 to $10,000 \mu \mathrm{mol} \cdot \mathrm{mol}^{-1} \mathrm{CO}_{2}$ (Wheeler et al., 1993). Although excess $\mathrm{CO}_{2}$ will be scrubbed through physical and chemical processes, plants can also play a role in reducing $\mathrm{CO}_{2}$ to acceptable levels by utilizing it in the photosynthetic process. The objective of this study was to evaluate the effects of increased $\mathrm{CO}_{2}$ partial pressures on growth, pod, and seed yield and gas exchange of 'Georgia Red' peanut grown hydroponically under controlled environments.

\section{Materials and Methods}

Experiments were conducted during 1996 and 1997. Three $\mathrm{CO}_{2}$ treatments were arranged in a randomized complete-block design with three replications over time. Three identical reach-in growth chambers (Environmental Growth Chambers, Chagrin Falls, Ohio), each with $1.39 \mathrm{~m}^{2}$ of growing area, were used.

Seeding. Seeds were planted in moist commercial Jiffy Mix (Geo. J. Ball, Batavia, Ill.) media in TLC Pro-Trays transplant flats (TLC Polyform, Plymouth, Minn.) and covered with $\approx 0.6 \mathrm{~cm}$ of the medium. Flats were placed in a growth chamber with a $28^{\circ} \mathrm{C}$ light $/ 22^{\circ} \mathrm{C}$ dark temperature, a 12-h photoperiod, and a constant relative humidity ( $\mathrm{RH}$ ) of $\approx 70 \% \pm 5 \%$. Seeds were watered every $3 \mathrm{~d}$ and seedlings were grown for $\approx 2$ weeks.

Transplanting. Before transplanting, seedlings were carefully removed from each cell and excess medium was removed, ensuring that minimal damage was done to the plant root system. The roots of the plants were gently washed with running tap water to remove particles of the medium that adhered to the roots. Four 2-week-old peanut seedlings were transplanted into each of two growing channels $(0.15 \times 0.15 \times 1.2 \mathrm{~m})$ through small openings $10 \mathrm{~cm}$ apart in a flexible black/white vinyl covering. This covering not only supported the plants, but served to prevent the entry of light into the pod development zone. At flowering, perforations were made in the vinyl covering to facilitate the entry of the developing gynophores into the pod production zone.

$\mathrm{CO}_{2}$ control. The $\mathrm{CO}_{2}$ treatments were 400 (ambient), 800, and $1200 \pm 25 \mu \mathrm{mol} \cdot \mathrm{mol}^{-1}$, maintained by using an infrared gas analyzer (Leybold-Heraeus, Wilhelm, Germany). The $\mathrm{CO}_{2}$ treatments were initiated $\approx 1$ week after transplanting and lasted for the duration of the experiment (110 d).

Nutrient solution. A modified halfHoagland (Hoagland and Arnon, 1950) nutri- 
ent solution was supplied to the plants in each channel. The nutrient solution was continuously pumped (Little Giant model 2 P037; Tecumseh Product Co., Oklahoma City, Okla.) from reservoirs $(30.4 \mathrm{~L})$ to the high end of each growth channel at a flow rate of $1 \mathrm{~L} \cdot \mathrm{min}^{-1}$, set by using a bypass line back to the reservoir with a control valve. Growth channels were inclined with a $1 \%$ slope to facilitate the return of the nutrient solution to the reservoir by gravity flow. The solution was replaced biweekly and was replenished with deionized water between changes. Nutrient solution $\mathrm{pH}$ was maintained between 6.4 and 6.7 by manual addition of either dilute $\mathrm{NaOH}$ or $\mathrm{HCl}$. Electrical conductivity was maintained between 1100 and $1200 \mu \mathrm{S} \cdot \mathrm{cm}^{-1}$ by adding a one-third Hoagland's stock, and solution temperature was similar to that of the air $\left(28 / 22^{\circ} \mathrm{C}\right)$.

Growth chamber conditions. Growth chamber conditions included a constant relative humidity of $70 \% \pm 5 \%$ and a photosynthetic photon flux $(P P F)$ of $600 \pm 50 \mu \mathrm{mol} \cdot \mathrm{m}^{-2} \cdot \mathrm{s}^{-1}$ at canopy level ( $\approx 20 \mathrm{~cm}$ above the plants) supplied by a mixture of cool-white fluorescent and incandescent lamps. Photoperiod was $12 \mathrm{~h}$ and temperature $28{ }^{\circ} \mathrm{C}$ light $/ 22^{\circ} \mathrm{C}$ dark.

Measurements. Biweekly starting $21 \mathrm{~d}$ after planting (DAP), the second fully expanded leaf on the main stem (growing axis) was detached for leaf area and dry weight determination. Mainstem and cotyledonary branch lengths were also recorded bi-weekly. Singleleaf gas exchange measurements were made using a LI-6400 portable photosynthesis system (LI-COR, Lincoln, Nebr.) with a red LED light source attachment. This open-flow system is designed to measure steady-state gas exchange under controlled temperature, humidity, $\mathrm{CO}_{2}$, and $P P F$ conditions. Measurements were made each day between 1000 and $1500 \mathrm{HR}$, using the third or fourth fully expanded, unshaded leaf from two plants per channel on a growing axis, resulting in four replicate leaves for each $\mathrm{CO}_{2}$ treatment. $\mathrm{CO}_{2}$ response curves were generated by measuring $\mathrm{CO}_{2}$ exchange rates (CER) at 11 points ranging from 55 to $1200 \mu \mathrm{mol} \cdot \mathrm{mol}^{-1} \mathrm{CO}_{2}$. Measurements were made at a leaf temperature of $28^{\circ} \mathrm{C}$, a $P P F$ of $1000 \mu \mathrm{mol} \cdot \mathrm{m}^{-2} \cdot \mathrm{s}^{-1}$, and a RH of $50 \%$. Carboxylation efficiencies (Farquhar and Sharkey, 1982) were determined from the initial slope of the $\mathrm{CO}_{2}$ response curve using linear regression on four points between 50 and $125 \mu \mathrm{mol} \cdot \mathrm{mol}^{-1}$ internal $\mathrm{CO}_{2}$.

Harvest. Plants were harvested 110 DAP and fresh weights of leaves, stems, roots, pods and seeds were determined. All fully expanded leaflets were removed from each plant and counted, and total leaflet area was determined using a LI-3100 leaf area meter (LI-COR). Fresh plant materials were dried for $72 \mathrm{~h}$ at 70 ${ }^{\circ} \mathrm{C}$. Pods were removed from each plant, counted, weighed, and dried at $35^{\circ} \mathrm{C}$ for $72 \mathrm{~h}$. After drying, pods were sorted into mature and immature and weighed. Seeds were removed from pods and categorized according to the method described by Rucker et al. (1994), as mature (seeds with a smooth testa, pink to dark pink with a more rounded appearance) or immature (light-colored seeds having testae with longitudinal wrinkles, and slightly elongated). The percentage of sound mature kernels [SMK; seeds without discoloration, mold, or sprouts (Davidson et al., 1982)] and harvest index $(\mathrm{HI} ; 100 \times$ seed dry weight/total dry weight) were also determined.

Experiments were repeated twice and treatments were rotated among chambers to minimize chamber effects. Data were combined by runs and analyzed by the General Linear Models procedure (SAS Institute, 1985).

\section{Results}

Foliage and stem fresh and dry weights were greater at 800 than at $400 \mu \mathrm{mol} \cdot \mathrm{mol}^{-1}$ $\mathrm{CO}_{2}$ but declined at $1200 \mu \mathrm{mol} \cdot \mathrm{mol}^{-1}$ (Table 1). Fibrous root dry weight increased linearly as $\mathrm{CO}_{2}$ increased.

Mature pod number and total fresh weight were not significantly affected by $\mathrm{CO}_{2}$ enrichment (Table 1), but total pod dry weight and immature pod number increased quadratically with increasing $\mathrm{CO}_{2}$.

Total seed dry mass increased with increasing $\mathrm{CO}_{2}$ (Table 1); the magnitude of increase was $36 \%$ from 400 (ambient) to 800 $\mu \mathrm{mol} \cdot \mathrm{mol}^{-1}$, but only $4 \%$ from 800 to 1200 $\mu \mathrm{mol} \cdot \mathrm{mol}^{-1}$. Number of mature seeds also increased with increasing $\mathrm{CO}_{2}$, but the yield of immature seeds and the percentage SMK were not influenced. HI increased with increasing $\mathrm{CO}_{2}$.

Increasing $\mathrm{CO}_{2}$ had no effect on dry matter accumulation in individual leaves (Table 2), but area per leaf and branch length (main and

Table 1. Effects of $\mathrm{CO}_{2}$ enrichment on vegetative growth, pod yield, seed yield and quality, and harvest index of 'Georgia Red' peanut.

\begin{tabular}{|c|c|c|c|c|}
\hline \multirow[b]{2}{*}{ Observation } & \multicolumn{4}{|c|}{$\mathrm{CO}_{2}\left(\mu \mathrm{mol} \cdot \mathrm{mol}^{-1}\right)$} \\
\hline & 400 & 800 & 1200 & Regression $^{2}$ \\
\hline \multicolumn{5}{|c|}{ Weight of foliage $\left(\mathrm{g} \cdot \mathrm{m}^{-2}\right)$} \\
\hline Fresh & 3850 & 5570 & 4120 & $\mathrm{~L}^{* *}, \mathrm{Q}^{* * \mathrm{z}}$ \\
\hline Dry $^{y}$ & 647 & 840 & 752 & $\mathrm{Q}^{*}$ \\
\hline \multicolumn{5}{|c|}{ Weight of stem ( $\mathrm{g} /$ plant $)$} \\
\hline Fresh & 75.3 & 120.4 & 87.6 & $\mathrm{~L}^{*}$ \\
\hline Dry & 13.5 & 18.9 & 15.2 & $\mathrm{~L}^{*}, \mathrm{Q}^{*}$ \\
\hline \multicolumn{5}{|c|}{ Weight of fibrous roots ( $\mathrm{g} /$ plant) } \\
\hline Dry & 1.96 & 2.04 & 2.83 & $\mathrm{~L}^{*}$ \\
\hline \multicolumn{5}{|c|}{ Number of pods $/ m^{2}$} \\
\hline Total & 673 & 850 & 1057 & NS \\
\hline Mature & 531.2 & 641.5 & 761.5 & NS \\
\hline Immature & 123.3 & 197.4 & 309.2 & $\mathrm{Q}^{*}$ \\
\hline \multicolumn{5}{|c|}{ Pod weight $\left(g \cdot m^{-2}\right)$} \\
\hline Total fresh & 1043 & 1241 & 1534 & NS \\
\hline Total dry & 326.5 & 479.8 & 510.0 & $\mathrm{Q}^{*}$ \\
\hline Immature dry & 7.5 & 12.1 & 10.2 & NS \\
\hline \multicolumn{5}{|c|}{ Number of seeds $/ m^{2}$} \\
\hline Mature & 706 & 865 & 1020 & $\mathrm{Q}^{*}$ \\
\hline Immature & 270 & 334 & 293 & NS \\
\hline \multicolumn{5}{|c|}{ Dry weight of seeds $\left(\mathrm{g} \cdot \mathrm{m}^{-2}\right)$} \\
\hline Total & 247 & 385 & 400 & $\mathrm{Q}^{*}$ \\
\hline Mature & 236 & 371 & 389 & $\mathrm{Q}^{*}$ \\
\hline Immature & 11 & 13 & 10 & NS \\
\hline \multicolumn{5}{|c|}{ Sound mature kernels (\%) } \\
\hline & 71 & 73 & 77 & NS \\
\hline \multicolumn{5}{|c|}{ Harvest index (\%) } \\
\hline & 24.5 & 29.1 & 32.0 & $\mathrm{~L}^{*}, \mathrm{Q}^{*}$ \\
\hline
\end{tabular}

${ }^{2} \mathrm{~L}=$ linear, $\mathrm{Q}=$ quadratic, significant at $P \leq 0.10(*)$ or $0.05(* *)$. NS = nonsignificant.

'Dry weight data are "air"-dry values. cotyledonary) increased linearly with increasing $\mathrm{CO}_{2}$. In contrast, specific leaf area decreased linearly as $\mathrm{CO}_{2}$ concentration increased from ambient to $1200 \mu \mathrm{mol} \cdot \mathrm{mol}^{-1}$.

Leaf net photosynthetic rate (Table 2) was highest in plants grown at $800 \mu \mathrm{mol} \cdot \mathrm{mol}^{-1}$ $\mathrm{CO}_{2}$. Stomatal conductance decreased, as expected, as the $\mathrm{CO}_{2}$ concentration increased, and was lowest at $1200 \mu \mathrm{mol} \cdot \mathrm{mol}^{-1}$, indicating a partial closure of stomates due to the high $\mathrm{CO}_{2}$. Carboxylation efficiency (Table 2), as determined from the initial slope of the $\mathrm{CO}_{2}$ response curve, was similar among plants grown at 400 and $800 \mu \mathrm{mol} \cdot \mathrm{mol}^{-1}$, but was lowest at $1200 \mu \mathrm{mol} \cdot \mathrm{mol}^{-1} \mathrm{CO}_{2}$. Net photosynthetic rate (Fig. 1) increased with internal $\mathrm{CO}_{2}$ concentration and was highest in those plants grown at $800 \mu \mathrm{mol} \cdot \mathrm{mol}^{-1} \mathrm{CO}_{2}$ and lowest for plants grown at $1200 \mu \mathrm{mol} \cdot \mathrm{mol}^{-1}$. Photosynthetic rates approached $\mathrm{CO}_{2}$ saturation at an internal $\mathrm{CO}_{2}$ concentration of $\approx 700 \mu \mathrm{mol} \cdot \mathrm{mol}^{-1}$.

\section{Discussion}

Production of above-ground biomass (Table 1) was highest in plants grown at 800 $\mu \mathrm{mol} \cdot \mathrm{mol}^{-1} \mathrm{CO}_{2}$. Pod yield (Table 1) increased linearly with $\mathrm{CO}_{2}$ enrichment. Hardy and Havelka (1977) reported higher dry matter and vegetative growth of peanut exposed to 1000 to $1500 \mu \mathrm{mol} \cdot \mathrm{mol}^{-1} \mathrm{CO}_{2}$ in field studies, and attributed this response to decreased photorespiration, delayed senescence, and increased plant density. Chen and Sung (1990) reported that field-grown peanut plants produced more biomass and higher pod yield at 
Table 2. Effects of $\mathrm{CO}_{2}$ enrichment on leaf and stem characteristics, net photosynthesis, stomatal conductance, and carboxylation efficiency of 'Georgia Red' peanut.

\begin{tabular}{lcccc}
\hline \hline & \multicolumn{3}{c}{$\mathrm{CO}_{2}\left(\mu \mathrm{mol} \cdot \mathrm{mol}^{-1}\right)$} \\
\cline { 2 - 5 } Observation & 400 & 800 & 1200 & Regression $^{2}$ \\
\hline Dry weight/leaf $(\mathrm{mg})$ & 193.0 & 188.0 & 183.0 & $\mathrm{NS}$ \\
Area/leaf $\left(\mathrm{cm}^{2}\right)$ & 30.9 & 36.4 & 38.9 & $\mathrm{~L}^{* * *}$ \\
Specific leaf area $\left(\mathrm{m}^{2} \cdot \mathrm{kg}^{-1}\right)$ & 24.8 & 21.2 & 22.1 & $\mathrm{~L}^{*}$ \\
Stem length $(\mathrm{cm})$ & & & \\
$\quad$ Main & 25.3 & 29.3 & 36.5 & $\mathrm{~L}^{*}$ \\
$\quad$ Cotyledonary & 23.1 & 26.2 & 33.2 & $\mathrm{~L}^{*}$ \\
Net photosynthesis $\left(\mu \mathrm{mol} \cdot \mathrm{mol}^{-1}\right)$ & 17.1 & 22.1 & 13.0 & $\mathrm{~L}^{*}$ \\
Stomatal conductance $\left(\mathrm{mol} \cdot \mathrm{m}^{-2} \cdot \mathrm{s}^{-1}\right)$ & 0.468 & 0.261 & 0.234 & $\mathrm{~L}^{*}$ \\
Carboxylation efficiency $\left(\mu \mathrm{mol} \cdot \mathrm{m}^{-2} \cdot \mathrm{s}^{-1}\right)$ & 0.111 & 0.116 & 0.069 & $\mathrm{~L}^{*}$ \\
\hline
\end{tabular}

${ }^{\mathrm{z}} \mathrm{L}=$ linear, $\mathrm{Q}=$ quadratic; significant at $P \leq 0.10(*)$ or $0.001(* * *)$. NS $=$ nonsignificant.

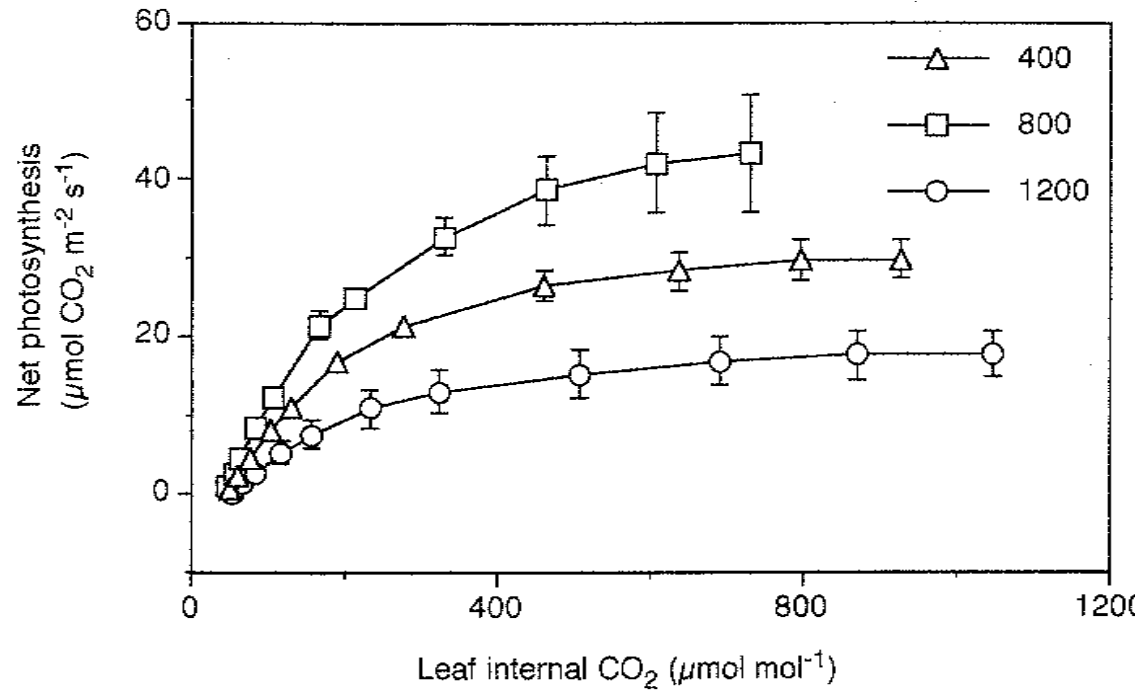

Fig. 1. Net photosynthesis ( \pm SE) as a function of internal $\mathrm{CO}_{2}$ in 'Georgia Red' peanut plants grown at three different $\mathrm{CO}_{2}$ concentrations. Curves are means of two to three replicate leaves from the second experiment (replicate).

$1000 \mu \mathrm{mol} \cdot \mathrm{mol}^{-1}$ than at ambient $\mathrm{CO}_{2}$. The increased biomass obtained in this study agrees with the findings of Chen and Sung (1990) and Hardy and Havelka (1977), but differs in that biomass production declined at the highest $\mathrm{CO}_{2}$ concentration. Vegetative growth is a continuous process in the peanut and has priority for all assimilates until pod and seed set commence (Boote et al., 1986, 1992). Pods and seeds then become stronger sinks for assimilates, thereby reducing that fraction available for vegetative growth. This phenomenon could partly explain the reduced vegetative growth, as evidenced by the fact that pod production (Table 2) and seed production (Table 1) tended to be higher at the highest $\mathrm{CO}_{2}$ level.

Pod dry weight (Table 1) was significantly higher at $1200 \mu \mathrm{mol} \cdot \mathrm{mol}^{-1} \mathrm{CO}_{2}$, reflecting both an increase in pod number as well as assimilate partitioning to the pods. According to Boote et al. (1992), physiological maturity in peanut is not as clearly defined as it is, for example, in soybean [Glycine $\max (\mathrm{L}$.) Merr.]. Pod number increases more gradually because vegetative growth continues during the seed growth phase, and pods of various stages of maturity are present at harvest.

Elevating $\mathrm{CO}_{2}$ from 400 to $1200 \mu \mathrm{mol} \cdot \mathrm{mol}^{-1}$ increased total seed yield an average of $37 \%$, the number of mature seeds by $25 \%$, and dry mass of mature seeds by $38 \%$ (Table 1 ). These results can be explained by a higher photosynthetic rate $(35 \%)$ in the enriched $\mathrm{CO}_{2}$ treatment (Table 2) particularly at the 800 $\mu \mathrm{mol} \cdot \mathrm{mol}^{-1}$ level, and paralleled those of Chen and Sung (1990), who reported higher seed yield of peanuts under elevated $\mathrm{CO}_{2}$ levels. Ackerson et al. (1984) attributed the high seed yields obtained for soybeans under $\mathrm{CO}_{2}$ enrichment to more pods and seeds per plant. In this study, the number of seeds produced was also significantly higher with than without enrichment. Although total seed yield increased by $36 \%$ when ambient levels of $\mathrm{CO}_{2}$ were raised to $800 \mu \mathrm{mol} \cdot \mathrm{mol}^{-1}$, the increase between 800 and $1200 \mu \mathrm{mol} \cdot \mathrm{mol}^{-1} \mathrm{CO}_{2}$ was only $4 \%$. This response could be related to several factors. First, the $1200 \mu \mathrm{mol} \cdot \mathrm{mol}^{-1} \mathrm{CO}_{2}$ may be near the toxic threshold for peanuts. Wheeler et al. (1993) reported a decrease in biomass and yield of soybean when $\mathrm{CO}_{2}$ exceeded $1000 \mu \mathrm{mol} \cdot \mathrm{mol}^{-1}$. The same may be true in peanut. Second, the decrease in foliage biomass and the marginal increase in seed yield could be an acclimation response. According to Arp (1991), long-term exposure to elevated $\mathrm{CO}_{2}$ causes a reduction in the activity of RuBP carboxylase and feedback inhibition of photosynthesis in both $\mathrm{C}_{3}$ and $\mathrm{C}_{4}$ species. This acclimation does not reduce growth, but prevents the increase in photosynthesis that normally occurs with elevated $\mathrm{CO}_{2}$. The reduction in the activity of RuBP carboxylase could partly explain the reduced photosynthetic rate among plants grown at $1200 \mu \mathrm{mol} \cdot \mathrm{mol}^{-1}($ Table 2). $\mathrm{CO}_{2}$ enrichment appeared to enhance maturity, as evidenced by the higher yield of mature seeds. In contrast, neither the number nor the weight of immature seeds was significantly influenced by $\mathrm{CO}_{2}$ enrichment (Table 1).

Harvest index (HI), which is an indication of the relative distribution of photosynthates between seeds and the remainder of the plant, was significantly increased by $\mathrm{CO}_{2}$ enrichment (Table 1). These results are not in agreement with those of Clifford et al. (1993), who reported that $\mathrm{HI}$ in peanut was not significantly influenced by $\mathrm{CO}_{2}$ enrichment. The reason for this difference may be due in part to the fact that plants were subjected to water stress in Clifford's study while in our study, plants were grown hydroponically.

Area per leaf and branch length increased with $\mathrm{CO}_{2}$ level (Table 2), while specific leaf area decreased as $\mathrm{CO}_{2}$ increased. Leaves of plants grown at 800 and $1200 \mu \mathrm{mol} \cdot \mathrm{mol}^{-1} \mathrm{CO}_{2}$ concentration had greater dry weights, and smaller areas, resulting in thicker leaves and thus reduced specific leaf area. Most of the difference in area per leaf occurred early in the growing period. At harvest neither total leaf area nor area per leaf was significantly affected by elevated $\mathrm{CO}_{2}$ (data not shown).

Carboxylation efficiency (Table 2) was similar among plants grown at 400 and 800 $\mu \mathrm{mol} \cdot \mathrm{mol}^{-1} \mathrm{CO}_{2}$, but decreased at 1200 $\mu \mathrm{mol} \cdot \mathrm{mol}^{-1}$. Chen and Sung (1990) reported greater carboxylation efficiency in peanut grown at $1000 \mu \mathrm{mol} \cdot \mathrm{mol}^{-1} \mathrm{CO}_{2}$ than at 340 $\mu \mathrm{mol} \cdot \mathrm{mol}^{-1} \mathrm{CO}_{2}$, indicating diversion of rubisco enzyme from oxygenation to carboxylation. Direct comparison of these results with ours is difficult owing to the differences in treatment levels. Perhaps the inhibitory effects of elevated $\mathrm{CO}_{2}$ on carboxylation efficiency do not become apparent until $\mathrm{CO}_{2}$ levels surpass $1000 \mu \mathrm{mol} \cdot \mathrm{mol}^{-1}$. Furthermore, Chen and Sung made no measurements below $200 \mu \mathrm{mol} \cdot \mathrm{mol}^{-1}$ internal $\mathrm{CO}_{2}$, relying instead on quadratic extrapolation from the measurements made at higher $\mathrm{CO}_{2}$ levels, leading to potentially large inaccuracies in their values.

The drop in leaf photosynthetic rates as $\mathrm{CO}_{2}$ was raised from 800 to $1200 \mu \mathrm{mol} \cdot \mathrm{mol}^{-1}$ (Table 2) is consistent with total biomass data and occurred despite a linear increase in the harvest index. There are reports of supraoptimal effects from $\mathrm{CO}_{2}$ on seed yield and total biomass of the soybean 'McCall' (Wheeler et al., 1993), seed set and vegetative growth in wheat (Triticum vulgare L.) (Bugbee et al., 1994; Grotenhuis and Bugbee, 1997; Reuveni and Bugbee, 1997), and in white potato (Solanum tuberosum L.) (Wheeler et al., 1996). The mechanism of varying plant responses at supraoptimal $\mathrm{CO}_{2}$ is not entirely clear. It may be mediated by low carbohydrate supply to developing embryos or by induction of ethylene synthesis by high $\mathrm{CO}_{2}$ (Bugbee et al., 1994; Grotenhuis and Bugbee, 1997; Reuveni and Bugbee, 1997). Developing peanut gynophores produce ethylene (Ketring et al., 1982), with the highest rates occurring during initial 
stages of growth (Lee et al., 1972), and just after penetration into the pod production zone (Hodges and Fletcher, 1979). This suggests that the high $\mathrm{CO}_{2}$ in our study may have interacted with the natural tendency of peanut gynophores to produce ethylene by increasing $\mathrm{CO}_{2}$-induced ethylene synthesis.

Increasing the $\mathrm{CO}_{2}$ from 400 to 1200 $\mu \mathrm{mol} \cdot \mathrm{mol}^{-1}$ decreased stomatal conductance by an average of $47 \%$ (Table 2). The partial closure of the stomates as $\mathrm{CO}_{2}$ increased paralleled the reduction in the rate of transpiration (data not shown). This was not unexpected, since extensive reports (Cure and Acock, 1986; Field et al., 1995; Morison, 1987; Zhu et al., 1998) have documented this phenomenon under high $\mathrm{CO}_{2}$ partial pressures.

This research clearly documents that doubling $\mathrm{CO}_{2}$ from 400 to $800 \mu \mathrm{mol} \cdot \mathrm{mol}^{-1}$ increased total seed yield and maturity, plant dry weight, and harvest index. However, the reduction in photosynthetic rate and plant biomass at $1200 \mu \mathrm{mol} \cdot \mathrm{mol}^{-1} \mathrm{CO}_{2}$ strongly indicates supraoptimal effects, the causes of which are not clearly understood, but are believed to be mediated by reduced carbohydrate supply or a $\mathrm{CO}_{2}$-induced increase in ethylene synthesis.

Generally, these results show that peanut responded positively to $\mathrm{CO}_{2}$ enrichment at least up to $800 \mu \mathrm{mol} \cdot \mathrm{mol}^{-1}$ and can be a useful crop in the ALS program. Although ambient $\mathrm{CO}_{2}$ concentration is not expected to approach 800 or even $1200 \mu \mathrm{mol} \cdot \mathrm{mol}^{-1}$ for several decades, in ALS, direct atmospheric exchange may be maintained between plant and human habitats in a sealed system. In such a case, $\mathrm{CO}_{2}$ partial pressures could be elevated beyond the levels used in this study. Further studies are in progress to evaluate peanut growth and development at higher concentrations of $\mathrm{CO}_{2}$.

\section{Literature Cited}

Ackerson, R.C., U.D. Havelka, and M.G. Boyle. 1984. $\mathrm{CO}_{2}$ enrichment effects on soybean physiology. II. Effects of stage-specific $\mathrm{CO}_{2}$ exposure. Crop Sci. 24:1150-1154.

Ahmed, E.M. and C.T. Young. 1982. Composition, quality, and flavor of peanuts, p. 655-688. In: H.E. Pattee and C.T. Young (eds.). Peanut science and technology. Amer. Peanut Res. and Educ. Soc., Yoakum, Tex.
Arp, W.J. 1991. Effect of source-sink relations on photosynthetic acclimation to elevated $\mathrm{CO}_{2}$. Plant Cell Environ. 14:869-875.

Bagnall, D.J. and R.W. King. 1991. Response of peanut (Arachis hypogaea) to temperature, photoperiod, and irradiance. 1. Effect on flowering. Field Crops Res. 26:261-300.

Bhagsari, A.S. and R.H. Brown. 1976 Photosynthesis in peanut (Arachis) genotype. Peanut Sci. $3: 1-5$.

Boote, K.J., J.W. Jones, J.W. Mishoe, and G.G. Wilkerson. 1986. Modeling growth and yield of groundnut, p. 243-254. In: Agrometeorology of groundnut. Proc. Intl. Symp. 21-26 Aug. 1985, ICRISAT Sahelian Center, Niamey, Niger. Patancheru, A.P. 502324, India: ICRISAT.

Boote, K.J., J.W. Jones, and P. Singh. 1992. Modeling growth and yield of groundnut, p. 331-343. In: Groundnut-A global perspective. Proc. Intl. Symp. 25-29 Nov. 1991, ICRISAT Center, India.

Bugbee, B., B. Spanarkel, S. Johnson, P. Monje, and G. Koerner. 1994. $\mathrm{CO}_{2}$ crop growth enhancement and toxicity in wheat. Adv. Space Res. 141:257-267.

Chen, J.J. and J.M. Sung. 1990. Gas exchange rate and yield responses of Virginia-type peanut to carbon dioxide enrichment. Crop Sci. 30:10851088.

Clifford, S.C. I.M. Stronach, A.D. Mohamed, S.N Azam-Ali, and N.M.J. Crout. 1993. The effects of elevated atmospheric carbon dioxide and water stress on light interception, dry matter production and yield in stands of groundnut (Arachis hypogaea L.). J. Expt. Bot. 44:17631770.

Cure, J.D. and B. Acock. 1986. Crop responses to carbon dioxide doubling: A literature survey. Agr. Forest Meteorol. 38:127-145.

Davidson, J.I., Jr., T.B. Whittaker, and J.W. Dickens. 1982. Grading, cleaning, storage, shelling, and marketing of peanuts in the United States, $p$. 501-620. In: H.E. Pattee and C.T. Young (eds.). Peanut science and technology. Amer. Peanut Res. and Educ. Soc., Yoakum, Tex.

Farquhar, G.D. and T.D. Sharkey. 1982. Stomatal conductance and photosynthesis. Annu. Rev. Plant Physiol. 33:317-345.

Field, C.B., R.B. Jackson, and H.A. Mooney. 1995. Stomatal responses to increased $\mathrm{CO}_{2}$ : Implications from the plant to the global scale. Plant Cell. Environ. 18:1214-1225.

Florh, M.-L., J.H. Williams, and F. Lenz. 1990. The effect of photoperiod on the reproductive developments of a photoperiod-sensitive groundnut (Arachis hypogaea L.) cv. NC AC 100090. Expt. Agr. 26:397-406.
Golueke, C.G. and W.J. Oswald. 1964. Role of plants in closed systems. Annu. Rev. Plant Physiol. 15:387-408.

Grotenhuis, T. and B. Bugbee. 1997. Super-optimal $\mathrm{CO}_{2}$ reduces seed yield but not vegetative growth in wheat. Crop Sci. 37:1215-1222.

Hardy, R.W.F. and U.D. Havelka. 1977. Possible routes to increase the conversion of solar energy to food and feed by grain legumes and cereal grains (crop production). $\mathrm{CO}_{2}$ and $\mathrm{N}_{2}$ fixation, foliar fertilization, and assimilate partitioning, p. 299-322. In: A. Mitsui (ed.). Biological solar energy conversions. Academic, New York

Hoagland, D.R. and D.I. Arnon. 1950. The water culture method for growing plants without soil. California Agr. Expt. Sta. Circ. 3407.

Hodges, R.A. and J. Fletcher. 1979. Ethylene evolution from peanut pegs. Plant Physiol. Suppl. 63:66.

Ketring, D.L. 1984. Temperature effects on vegetative and reproductive development of peanuts. Crop Sci. 24:877-882.

Ketring, D.L, R.H. Brown, G.A. Sullivan, and B.B. Johnson. 1982. Growth physiology, p. 411-457. In: H.E. Pattee and C.T. Young (eds.). Peanut science and technology, APRES, Yoakum, Texas.

Krall, A.R. and B. Kok. 1960. Studies on algal gas exchangers with reference to space flight. Dev. Indust. Microbiol. 1:33-44.

Lee, T.A., D.L. Ketring, and R.D. Powell. 1972 Flowering and growth response of peanut plants (Arachis hypogaea L. var. Starr) at two levels of relative humidity. Plant Physiol. 49:190-193.

MacElroy, R.D. and J. Bredt. 1985. Current concepts and future directions of CELSS. NASA Conf. Publ. 2378

Morison, J.J.L. 1987. Intercellular $\mathrm{CO}_{2}$ concentrations and stomatal responses to $\mathrm{CO}_{2}$, p. 229 251. In: E. Zeiger, G.D. Farquhar, and I.R. Cowan (eds.). Stomatal function. Stanford Univ. Press, Stanford, Calif

Rucker, K.S., C.K. Kvien, G. Vellidid, N.S. Hill, and J.K. Sharpe. 1994. A visual method of determining maturity of shelled peanuts. Peanut Sci. 21:141-146.

SAS Institute. 1985. SAS user's guide. Statistics, version 5 ed. SAS Inst., Cary, N.C.

Wheeler, R.M., C.L. Mackowiak, L.M. Siegrest, and J.C. Sager. 1993. Supraoptimal carbon dioxide effects on growth of soybean [Glycine $\max$ (L.) Merr.]. J. Plant Physiol. 142:173-178.

Zhu, J., L.D. Talbott, X. Jin, and E. Zeiger. 1998 The stomatal response to $\mathrm{CO}_{2}$ is linked to changes in guard cell zeaxanthin. Plant Cell Environ. 21:813-920. 